\title{
INTERNATIONAL RELATIONS OF JAPAN WITH THE COUNTRIES OF CENTRAL ASIA
}

Abdumalikova Muslima - 2-nd course master at Tashkent state institute of oriental studies

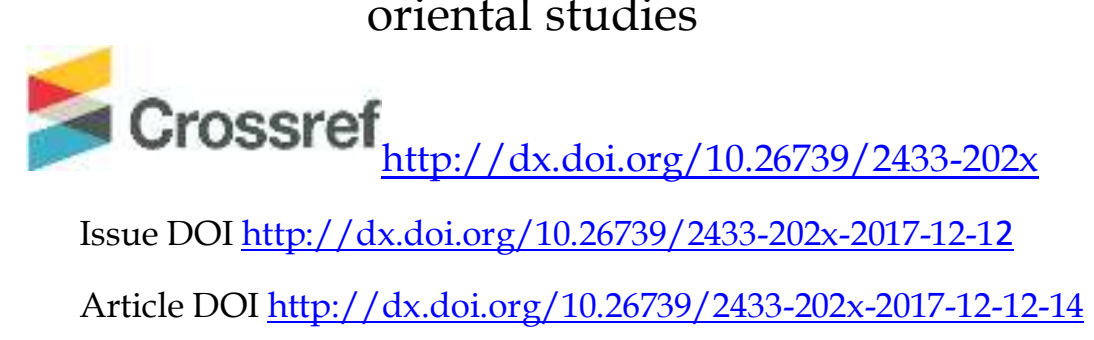

Annotation: This article is devoted to the international relations of Japan with the countries of Central Asia. In recent years, Japan's interest in the countries of Central Asia has been increasing, due to the protection of its own energy. This is the main message of the Central Asian countries to Japan, as well as the Prime Ministers of Japan. Koizumi and Shinzo Abe in Central Asia. Japan one of the largest economic centers of the world.

However, as a politically independent and influential world power no. It is the discrepancy of the economic weight to political significance that does not allow the country of the rising sun to be considered a full-fledged center of power in world politics. However, this does not mean at all that Japan is abandoning attempts to change the existing situation. Quite the opposite, every year she is stepping up efforts to expand the range of political and economic tasks that she is solving. Eloquent evidence of this can be the policy pursued by it in Central Asia. According to the famous British geographer and political scientist $\mathrm{H}$. Mackinder, the key to the domination of peace is in the Eurasian continent. Eurasia is the center of the world, and Central Asia is the heart of the continent.

Key words: Central Asia, region, international relations, national interests, diplomacy, security, cooperation, world politics, soft power.

Abdumalikova Muslima 
What is the basis of her interests in this region? First, let us give due to Japanese pragmatism - purely economic expediency, and only then specific political goals. With its success, Japan owes too economic assistance from the United States, and now it is its turn to help other countries and thus "to find friends who understand and support the Japanese position" [i] . Tokyo pays great attention to building relations and gaining political weight in the states receiving this assistance.

In the opinion of the Japanese Foreign Ministry, the deepening interdependence of the modern world puts the country in a situation in which its security and prosperity are directly linked to the stability and wellbeing of all the other members of the international community and, therefore, forces them to work closely with them to achieve their goals. "In this regard, assisting developing countries in solving their internal problems through the provision of ODA ultimately means supporting the well-being of their own people. At the same time the Japanese government should be convinced of the need to support developing countries and other major donor state ", noted in the" Blue Book " [ii] .

As already indicated, ODA is one of the main channels through which financial and other assistance is received from Japan, which is one of the world leaders under the Official Development Assistance Program. The economic interests of the country of the rising sun in Central Asia are due primarily to the hydrocarbon resources of the region and the search for optimal ways of their transportation. Basically we are talking about the oil and gas of Uzbekistan, Turkmenistan and Kazakhstan [iii] .

The economic cooperation of the countries of the region with Japan is currently determined mainly by projects funded by its government under the program of assistance to economic reforms in the CIS. As a rule, this assistance is provided through the Japanese governmental organizations for international cooperation - the Agency for International Cooperation (JICA) and the Economic Cooperation Fund with Foreign Countries (OECF) [iv] .

Funding has been started for projects related to the development of rich natural resources, primarily oil, gas, gold, uranium, and the development of a telecommunications network whose absence or unsatisfactory condition is a problem common to all Central Asian countries. In total, according to 1996 data, the Japanese side invested about 310 million dollars in the economy of 
Uzbekistan in the form of investments, and the total value of projects that are at the stage of coordination exceeds $\$ 800$ million .

Kazakhstan imports from the country of the rising sun machinery and equipment, vehicles and consumer goods (electronic home appliances, TVs, transistors, etc.). The main export items to Japan: fuel, mineral raw materials, chemical products, ferrous and non-ferrous metallurgy, construction materials. An objective obstacle to the growth of trade between Japan and Central Asia is geographical remoteness.In addition, the Japanese side is not satisfied with the fact that almost all transport interchanges of the region are oriented towards Russia. A significant negative factor is the high tariffs for the transit of goods through China $[\mathrm{v}]$.

To fill its new foreign policy with concrete content, the Japanese government adopted a plan called the Program of Action on Diplomacy of the Great Silk Road. It involves the development of broad political ties, comprehensive economic cooperation, assistance in the transition to a market economy.

No state in Central Asia has access to the world's oceans, they are all cut off from the main trade routes. Thus, the integration of the region into the global economic space, without which the prospects of all five countries seem at best problematic, "blocked" by geography. In this situation, the "Revival of the Great Silk Road" will allow us to overcome the geographic isolation of Central Asia and to open the world to its economy.

The revival of the Great Silk Road is a new project of the interested countries, called for in the 21st century to ensure the stable and close economic, political and cultural cooperation of the states located all along it. At the current stage of the development of this concept, the economic role is undoubtedly the dominant role.

The Great Silk Road is supposed to be built on three pillars: energy, transcontinental transport system and telecommunications. The core of the project, which accumulates global, regional and local interests, is the development of the region's natural resources, primarily large oil and gas fields. Using the raw potential of Central Asia would make the necessary dynamism to the local economy, and a major energy importers - to ensure a stable supply of raw materials. This stimulates the integration of the region into global systems of transport and information communications.

The diplomatic concept of the country is Prime Minister Ryutaro Hashimoto's "Eurasian diplomacy", which presupposed economic and political cooperation between Japan, Russia and the countries of Central

Abdumalikova Muslima 
Asia [vi] . According to this document, Japan's policy towards Central Asia contains three main principles:

- $\quad$ - political dialogue on deepening trust and mutual understanding;

- - economic cooperation and cooperation in the development of natural resources to ensure prosperity in the region;

- - The achievement of peace in the region through the nonproliferation of nuclear weapons, democratization and stabilization.

Japan is one of the country's most consistently contributing to the project, as evidenced by its official assistance to the CIS countries. In the development of the transcontinental transport network, priority is given to rail transport. First, when transporting for long distances, it is more economical than automobile. Secondly, it is only by rail to Central Asia that it is possible to deliver multi-tonn equipment and pipes necessary for the operation of oil and gas fields and the construction of main pipelines. In this regard, Uzbekistan promising route Andijan -Osh - Irkeshtam (the border of Kyrgyzstan and China) - Kashgar (China). It will connect the railways of China and the joint network of steel mains of Central Asia, as well as Iran, will open the possibility of transport communication with Shanghai, the Korean port of Busan, the Japanese port of Osaka, and also the ports of other countries of South-East Asia [vii].

The second most important is the air way. Within the framework of ODA, the Japanese government allocated large grants for the reconstruction of the main airports of Kyrgyzstan and Uzbekistan, the repayment of which is designed for several years. Among other things, this means that the air communication between Europe and Asia will gradually shift to the south of the Eurasian continent, and Central Asia will turn into an important transit point along the way.

If the energy and transport routes are not the nearest future, the region will join the global telecommunications space at a rapid pace.Due to its geographical position, it is given an important place in the global project of the Trans - Asian - Trans - European fiber-optic backbone.

In early June 2017, Japanese Prime Minister Shinzo Abe made a statement that, at first glance, might seem unprecedented: S. Abe $\underline{\mathrm{He}}$ expressed willingness to cooperate with Beijing on the initiative "One belt one way". The last significant moment in these relations was the tour of the Japanese prime minister for Central Asia in October 2015. This trip was bright due to the contrast with the less pronounced interest of $S$. Abe's predecessors to the region, and also due to the aggregate value of the concluded

Abdumalikova Muslima 
agreements of $\$ 27$ billion [viii]. At the same time, despite the fact that observers often interpret S. Abe's tour as a special case of Japan's general Asian rivalry with China, the subsequent activity of Tokyo in the Central Asian region was characterized not so much by loud initiatives as by the gradual development of practical projects, primarily economic interest.

Analyzing the activity of Japan in Central Asia, come $m$ to the conclusion that the land of the rising sun are attracted to the region not only economic aspects, but also, as already mentioned, great political interests. If you look at the history of the development of Japanese ODA, a rather interesting picture emerges. Currently, in Japan itself, no one doubts that in the 21st century it will play a more independent role. In the meantime, official development assistance is in fact the only diplomatic card that Tokyo can walk without regard to Washington. And in this respect, Japan pursues a fairly consistent policy aimed at developing a more independent course. 


\section{References}

1. Cherevko YU.M. Yaponiya: konets XX veka. Yaponskaya ofitsial'naya pomosh razvitiyu: uroki i perspektivi. - Moskva: Mejdunarodnie otnosheniya, 2014. - S. 25.

2. Komissina IN Yaponiya i Sentral naya Aziya: partnerstvo nabiraet silu / / Sentral`naya Aziya i Kavkaz. 2014. - No. 2. - SS. 78-82.

3. PanOrient on Japanese-Uzbek Relations.13.02.2011 - http // mewpacificinstitute.org / jsw / ? P $=4727$

4. Komissina IN Aziatskiy vektor politiki Uzbekistana. - Uzbekistan: obretenie novogo oblika. -Moskva, 2017.-T. 2. - S. 380.

5. Reznikova O. Sentral'naya Aziya i ATR // Mirovaya ekonomika i mejdunarodnie otnosheniya. - Moskva, 1999. - No. 4. - SS. 98-102.

6. Shaymardanova N. Demokratiya po-yaponski // Analytic. Informatsionno - analiticheskiy jurnal . 2016. - No. 2. - S .19-24

7. Nurgaliev M. Perspektivi Yaponii v Shanxayskoy organizatsii sotrudnichestva / / Sentral`naya Aziya i Kavkaz. - Moskva. 2015. - No. 1. SS.

8. 109-117.

9. Kistanov VO Vneshnyaya politika Yaponii v 2015 godu: kuda poydyot peregruzka? // Problemi Dal’nego Vostoka. - Moskva, 2015. - No. 3. - SS. 2940 . 